\author{
Agnieszka Kłos \\ Uniwersytet Pedagogiczny \\ im. Komisji Edukacji Narodowej \\ w Krakowie
}

\title{
Rola przedsiębiorczości wladz i mieszkańców gminy Horyniec-Zdrój w aktywizacji gospodarczej regionu
}

Współczesne procesy rozwoju społeczno-gospodarczego i kulturowego w różnej skali układów przestrzennych wykazują coraz silniejsze powiązania z procesami rozwoju globalnego. Procesy te $\mathrm{z}$ jednej strony przyczyniają się do pobudzania konkurencyjności podmiotów gospodarczych, z drugiej strony powodują podnoszenie atrakcyjności układów przestrzennych dla generowania endogenicznych i przyciągania egzogenicznych czynników rozwoju (Zioło 2007).

Powszechnie przyjmuje się, że ,przedsiębiorczość stanowi podstawowy warunek rozwoju gospodarczego, społecznego i kulturowego układów przestrzennych różnej skali” (Zioło 2007, s. 10). W związku z tym niezbędne jest więc kształtowanie postaw przedsiębiorczych w całym społeczeństwie.

Pod pojęciem przedsiębiorczość należy rozumieć takie zachowania władz i miejscowej ludności, które zmierzają do poszukiwania nowych zastosowań posiadanych zasobów w celu aktywizacji gospodarczej regionu (Majewska 2006). Przedsiębiorczość jest zatem zespołem określonych cech osobowych człowieka, które pozwalają mu aktywnie uczestniczyć w życiu społeczno-gospodarczym (Fedan 2005). Aktywność społeczna, pobudzając dany obszar lub ośrodek osadniczy, przyspiesza jego rozwój.

W niniejszych rozważaniach podjęto problematykę roli i znaczenia samorządu gminnego w pobudzaniu przedsiębiorczości lokalnej oraz zwrócono uwagę na przedsiębiorczość samych władz, jak również przejawy przedsiębiorczości mieszkańców i znaczenie przedsiębiorczości zbiorowej w pobudzaniu rozwoju społeczno-gospodarczego gminy Horyniec-Zdrój. Istotne staje się bowiem pytanie o możliwość rozwoju gminy w warunkach nasilającej się globalizacji, a więc także rosnącej konkurencji. Prezentowane wyniki badań stanowią fragmenty pracy magisterskiej pt.: Analiza rozwoju funkcji uzdrowiskowej gminy Horyniec-Zdrój w latach $1995-2008^{1}$.

Należy zwrócić uwagę na fakt, że poszczególne układy przestrzenne stwarzają odmienne warunki dla pobudzania i kształtowania się na ich obszarze procesów rozwoju społeczno-gospodarczego, co ma związek z różnym stopniem konkurencyjności w zakresie generowania wewnętrznych i przyciągania zewnętrznych czynników rozwoju (Kudełko 2005). W wypadku gminy Horyniec-Zdrój owe odmienne warunki są stwarzane dzięki posiadaniu zasobów surowców balneologicznych.

\footnotetext{
${ }^{1}$ Praca została napisana w Zakładzie Przedsiębiorczości i Gospodarki Przestrzennej Instytutu Geografii Uniwersytetu Pedagogicznego w Krakowie w roku akademickim 2009/2010 pod kierunkiem Pani prof. dr hab. inż. arch. Elżbiety Kaczmarskiej oraz przy pomocy Pani dr Moniki Borowiec i Pani mgr Wioletty Kilar.
} 
Badana gmina położona jest w powiecie lubaczowskim, w województwie podkarpackim, na terenie dwóch krain fizyczno-geograficznych: Płaskowyżu Tarnogrodzkiego i Roztocza Wschodniego. Południowo-wschodnia granica gminy jest jednocześnie granicą państwową z Ukrainą (ryc. 1.). Horyniec-Zdrój położony jest $\mathrm{z}$ dala od wielkich aglomeracji, od najbliższego ośrodka miejskiego liczącego ponad 100 tys. mieszkańców, Rzeszowa, wieś dzieli odległość $110 \mathrm{~km}$. Dzięki temu, że na terenie gminy Horyniec-Zdrój występują zarówno pokłady borowiny, jak i źródła leczniczych wód siarczkowo-siarkowodorowych, możliwe było utworzenie w niej uzdrowiska.

Należy pamiętać, że funkcja uzdrowiskowa jest szczególna z tego względu, że nie każda miejscowość może ją pełnić. W Polsce jedynie 44 miejscowości spełniają kryteria pozwalające na uzyskanie statusu uzdrowiska - ich rozmieszczenie zostało przedstawione na rycinie 1.

Ryc. 1. Położenie Horyńca-Zdroju na tle pozostałych uzdrowisk statutowych w Polsce

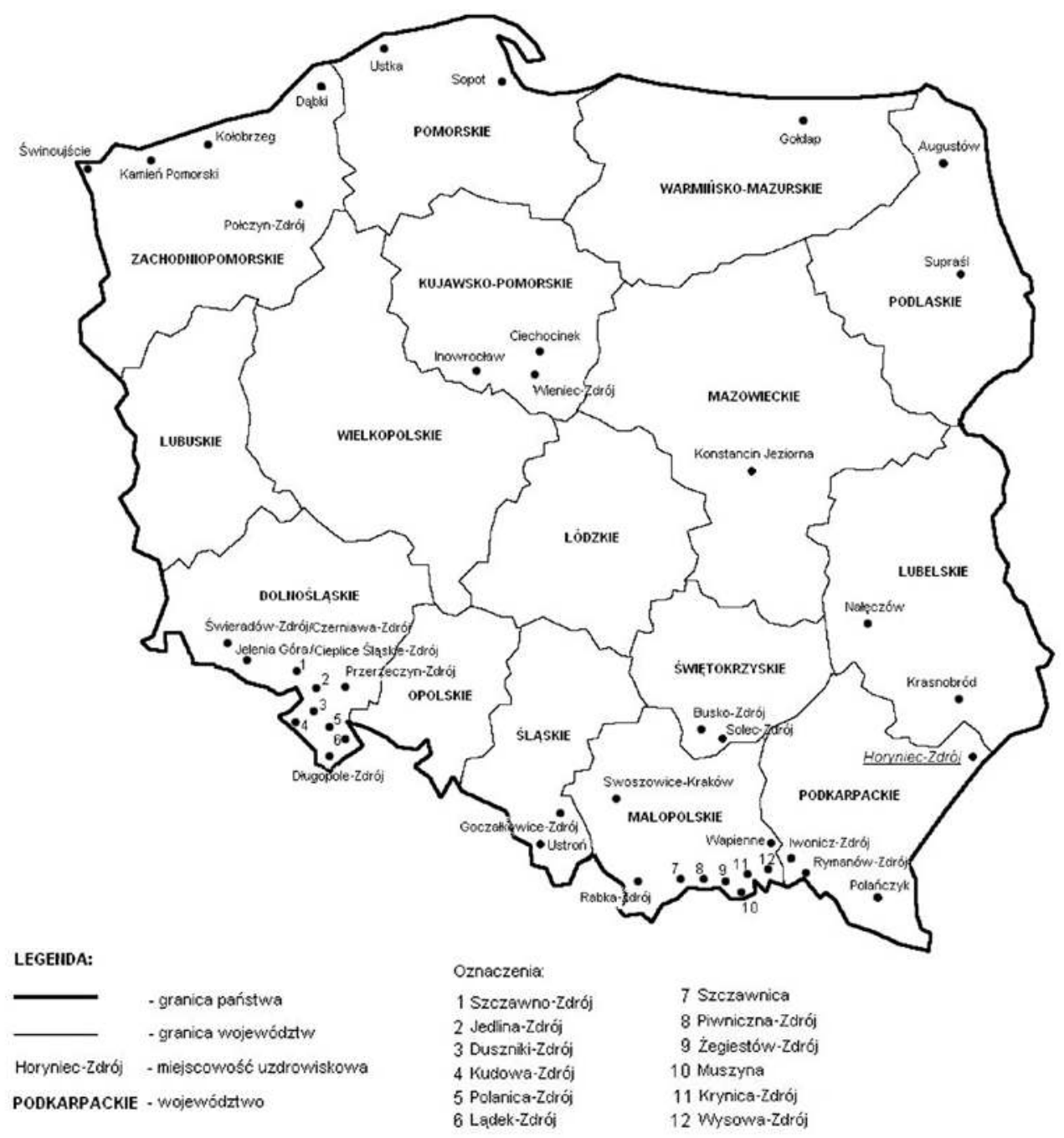

Źródło: opracowanie własne na podstawie danych z www.mz.gov.pl oraz Kajoch 1990. 
Rozwój uzdrowiska wiąże się co prawda z wieloma ograniczeniami, ale pociąga za sobą także wiele korzyści - ma wpływ na rozwój miejscowości poprzez oddziaływanie na wiele aspektów różnych dziedzin życia: wymusza rozwój innych form działalności i, odpowiednio wykorzystany, może stanowić czynnik rozwoju lokalnego. Przyjmuje się, że jedno miejsce pracy w lecznictwie uzdrowiskowym generuje aż siedem miejsc pracy w usługach pokrewnych (Golba 2002).

Posiadanie statusu uzdrowiska może stać się dobrym czynnikiem marketingowym, zapewniającym o tym, że dany obszar może się poszczycić m.in. czystym środowiskiem i zasobami naturalnych surowców leczniczych. Należy jednak pamiętać, że uzdrowiska to miejscowości często monofunkcyjne. Ograniczenia związane z posiadaniem statusu uzdrowiska utrudniają bowiem lub wręcz uniemożliwiają prowadzenie działalności gospodarczej w tych dziedzinach, które kolidują z funkcjami uzdrowiskowymi, a co za tym, idzie aktywność gospodarcza mieszkańców jest ograniczona.

Ponadto na obszarach posiadających status uzdrowiska lub status obszaru ochrony uzdrowiskowej wydziela się trzy rodzaje stref w celu ochrony naturalnych surowców leczniczych, czynników leczniczych oraz klimatu. Są to: strefa ochronna A, B oraz C. We wszystkich tych strefach obowiązują pewne ograniczenia co do lokalizacji w nich obiektów oraz prowadzonej na ich terenie działalności. Najostrzejsze ograniczenia obowiązują w strefie A (strefa ścisłej ochrony uzdrowiskowej), gdzie zabrania się m.in.: lokalizacji zakładów przemysłowych, domków turystycznych i campingowych, stacji benzynowych, stacji nadawczych radiowych i telewizyjnych oraz innych emitujących fale elektromagnetyczne (Ustawa z dnia 28 lipca $2005 \mathrm{r}$. o lecznictwie uzdrowiskowym, uzdrowiskach i obszarach ochrony uzdrowiskowej oraz o gminach uzdrowiskowych, Dz.U. z dnia 1 września 2005 r.).

Pożądanym kierunkiem działań samorządu powinno być zatem wykorzystanie regionalnej specyfiki i lokalnych zasobów wewnętrznych, szczególnie tych niepowtarzalnych i charakterystycznych, do stymulowania rozwoju gospodarczego, a także tworzenia odpowiednich warunków do wyzwolenia postaw przedsiębiorczych społeczeństwa. Region może bowiem osiągnąć przewagę konkurencyjną jedynie wówczas, gdy wykorzystane zostaną jego indywidualne cechy, a zarazem wewnętrzne siły konkurencyjne regionu dostosują się do warunków i wymagań globalnego otoczenia.

Po roku 1989 funkcja uzdrowiskowa zaczęła być postrzegana jako motor i stymulator rozwoju gminy i całego regionu, w tym także terenów przygranicznych. Zaczęto dostrzegać indywidualne wartości miejscowości uzdrowiskowych jako podstawowe wartości gminy, stanowiące główne źródło jej dochodów (Kaczmarska 2002). Także władze gminy Horyniec-Zdrój dostrzegły możliwości rozwijania swojego terytorium poprzez funkcję uzdrowiskową. W globalizującym się świecie i rosnącej konkurencji oraz w czasach, gdy powstają liczne ośrodki odnowy biologicznej i popularne stają się wczasy spa, ważne jest, aby uzdrowisko było atrakcyjnym miejscem, do którego ludzie będą chcieli przyjeżdżać w celu poprawy stanu zdrowia, regeneracji sił fizycznych i psychicznych. W dokumentach strategicznych gminy podkreśla się potrzebę realizacji działań mających na celu rozwój funkcji uzdrowiskowej jako dominującej, a obsługę lecznictwa uzdrowiskowego jako jednego z głównych źródeł utrzymania mieszkańców.

Władze gminy sukcesywnie podejmują działania zmierzające do osiągnięcia zamierzonych celów. Dokonano już wielu inwestycji, a plany zarówno władz gminy, jak i władz zakładów uzdrowiskowych przewidują kolejne działania. Dotychczas wyremontowano deptak w centrum miejscowości oraz modernizowano i rozbudowano infrastrukturę w Parku Zdrojowym, ukończono również budowę ścieżek rowerowych. W bieżącym roku przewiduje się także zakończenie modernizacji ciągu pieszego prowadzącego z Dzielnicy Lecznictwa Uzdrowiskowego przez przejście podziemne do centrum miejscowości (Plan odnowy miejscowości na lata 2007-2013). 
Przed władzami gminy wciąż jednak jeszcze wiele inwestycji do zrealizowania. Z myślą o mieszkańcach, kuracjuszach, turystach i uczestnikach szkoleń oraz konferencji na lata 2010-2011 przewidziana została adaptacja budynku byłej siedziby PGR w Horyńcu-Zdroju na świetlicę wiejską. W decydującą fazę wkraczają prace przy budowie boiska ORLIK przy gimnazjum w Horyńcu-Zdroju, a w 2011 r. planowane jest ukończenie modernizacji stadionu sportowego. Do 2012 r. mają zostać ukończone budowy parkingów, głównie w centrum miejscowości. W celu podniesienia atrakcyjności turystycznej i zwiększenia powierzchni obszarów rekreacyjno-wypoczynkowych, do 2013 r. ma zostać zagospodarowane nadbrzeże zalewu na Radrużce. Planowane inwestycje zostały uwzględnione w budżecie gminy i będą finansowane zarówno ze środków własnych gminy, jak i z dotacji Programu Rozwoju Obszarów Wiejskich i Regionalnego Programu Operacyjnego Województwa Podkarpackiego (Lokalna strategia rozwoju Grupy Działania ,, Serce Roztocza” na lata 2009-2015; Plan rozwoju lokalnego Gminy Horyniec-Zdrój na lata 2005-2013; Plan odnowy miejscowości na lata 2007-2013).

Ponadto Gminny Ośrodek Pomocy Społecznej w Horyńcu-Zdroju w ramach programu operacyjnego Kapitał Ludzki realizuje projekt pt. „Czas na aktywność w gminie Horyniec-Zdrój”. Program jest przeznaczony dla osób długotrwale bezrobotnych korzystających ze świadczeń pomocy społecznej. Jego celem jest kształcenie aktywnych i przedsiębiorczych postaw zawodowych na otwartym rynku pracy oraz zapewnienie osobom dyskryminowanym na rynku pracy równego dostępu do zatrudnienia oraz podwyższenia ich statusu zawodowego i społecznego poprzez podniesienie samooceny, kwalifikacji, nabycia umiejętności interpersonalnych i pracy w zespole. Na realizację programu Gminny Ośrodek Pomocy Społecznej otrzymał dotację ze środków Europejskiego Funduszu Społecznego.

Ponadto, w ślad za trendami panującymi w uzdrowiskach, w Horyńcu-Zdroju już kilkukrotnie zostały zorganizowane konferencje naukowe. W dniach 5-7 maja 2000 r. odbyła się tu Międzynarodowa Konferencja Naukowa pt. „Agroturystyka szansą aktywizacji przygranicznego powiatu lubaczowskiego w aspekcie przystąpienia do Unii Europejskiej”. Rok później, w dniach 18-19 maja, miała miejsce kolejna Międzynarodowa Konferencja Naukowa pt. „Problemy ochrony środowiska i dziedzictwa kulturowego w przygranicznym pasie Polski i Ukrainy - region Roztocza". Natomiast w dniach 22-23 kwietnia 2002 r. Horyniec-Zdrój był miejscem obrad Międzynarodowej Konferencji „Forum Gospodarcze Polska - Ukraina”. Wydarzenia te zgromadziły wielu wybitnych naukowców z takich ośrodków naukowych, jak Warszawa, Kraków, Katowice, Lublin, Rzeszów, Częstochowa i Lwów oraz przedstawicieli władz rządowych i samorządowych. Ponadto 28 września 2008 r. w Horyńcu-Zdroju miało miejsce posiedzenie Zarządu Stowarzyszenia Gmin Uzdrowiskowych RP (www.ughoryniec.iap.pl).

Gmina Horyniec-Zdrój jest członkiem Lokalnej Grupy Działania „Serce Roztocza”, w skład której wchodzą również dwie sąsiednie gminy - Cieszanów i Narol. Biorąc pod uwagę uwarunkowania regionu, głównym celem tego stowarzyszenia jest rozwiązywanie wspólnych problemów z zakresu infrastruktury, ochrony środowiska, rynku pracy. Za ważny cel uznano także promocję obszaru oraz upowszechnianie wiedzy o nim (Lokalna strategia rozwoju Grupy Działania ,,Serce Roztocza” na lata 2009-2015).

Ponadto Gmina Horyniec-Zdrój w partnerstwie z miastem Tomaszów Lubelski realizuje projekt „Wspólne działania promocyjne miast Tomaszów Lubelski i Horyniec-Zdrój szansą na dynamiczny rozwój gospodarczy Roztocza Środkowego i Wschodniego”. Projekt ten ma na celu zwiększenie popularności turystycznej i gospodarczej regionu i jest realizowany w ramach Programu Operacyjnego Rozwój Polski Wschodniej. W ramach tego projektu ukazała się w bieżącym roku publikacja pt. Horyniec-Zdrój i okolice, wydana w języku polskim i angielskim (www.ughoryniec.iap.pl). 
Warto zauważyć również, że w roku 2006 gmina Horyniec-Zdrój została laureatem konkursu „Gminy FAIR PLAY”. Oznacza to, że kreuje dobre wzorce współpracy samorządów z przedsiębiorcami - wzorce godne naśladowania przez wszystkie jednostki administracyjne. Wyróżnienie to oznacza również, że gmina jest otwarta na nowe inicjatywy gospodarczo-inwestycyjne i zapewnia przyjazny klimat dla inwestorów oraz profesjonalną obsługę inwestycyjną.

Niekorzystnym zjawiskiem w aspekcie rozwoju postaw przedsiębiorczych i funkcji uzdrowiskowej jest wciąż niewystarczający rozwój infrastruktury. Dalszych przedsięwzięć w tym zakresie wymaga przede wszystkim poprawa stanu dróg, budowa planowanej od dawna obwodnicy Horyńca-Zdroju i gazyfikacja gminy, która jak dotychczas nie została przeprowadzona. Ponadto władzom zależy na stworzeniu ogólnogminnego systemu gospodarki odpadami, pełnego zwodociągowania obszaru gminy, rozbudowy i modernizacji gminnego składowiska odpadów. Władze dostrzegają także możliwość budowy siłowni wiatrowych w rejonie Radruża, co niewątpliwie przyczyni się do dbałości o ochronę środowiska (Strategia rozwoju Gminy Horyniec-Zdrój na lata 2005-2013; Program ochrony środowiska dla Gminy Horyniec-Zdrój 2005).

Tab. 1. Zmiany liczby kuracjuszy lecznictwa zamkniętego uzdrowisk w Horyńcu-Zdroju w latach 1995-2008

\begin{tabular}{|c|c|c|}
\hline Rok & $\begin{array}{c}\text { Liczba kuracjuszy } \\
\text { lecznictwa zamkniętego }\end{array}$ & $\begin{array}{c}\text { Dynamika } \\
\mathbf{( 1 9 9 5}=\mathbf{1 0 0} \%)\end{array}$ \\
\hline 1995 & 4859 & 100,00 \\
\hline 1996 & 5647 & 116,22 \\
\hline 1997 & 6432 & 132,37 \\
\hline 1998 & 7121 & 146,55 \\
\hline 1999 & 6640 & 136,65 \\
\hline 2000 & 8047 & 165,61 \\
\hline 2001 & 7848 & 161,51 \\
\hline 2002 & 8749 & 180,06 \\
\hline 2003 & 8856 & 182,26 \\
\hline 2004 & 9209 & 189,52 \\
\hline 2005 & 9327 & 191,95 \\
\hline 2006 & 9076 & 186,79 \\
\hline 2007 & 9661 & 198,83 \\
\hline 2008 & 9671 & 199,03 \\
\hline
\end{tabular}

Źródło: opracowanie własne na podstawie danych GUS (www.stat.gov.pl).

Aktywność oraz postawy przedsiębiorcze przejawia również kadra zarządzająca uzdrowiskami. Należy pamiętać, że dziś, funkcjonując w społeczeństwie konsumpcyjnym, uzdrowiska muszą dostosować się do twardych reguł rynku, rosnącej konkurencji i nierzadko wygórowanych wymagań klientów, aby w dalszym ciągu móc prosperować. Dlatego też Uzdrowisko Horyniec Sp. z o.o. zainwestuje w nowy pawilon o podwyższonym standardzie dla prawie 100 kuracjuszy oraz rozbuduje zakład przyrodoleczniczy. Budowa nowego obiektu wiązać się będzie 
ze zwiększeniem zatrudnienia o 35-40 osób. Natomiast Centrum Rehabilitacji Rolników KRUS, w ślad za trendami obowiązującymi w uzdrowiskach zachodniej Europy, zainwestowało w rozbudowę swojej bazy rekreacyjnej i w 2006 r. otworzyło krytą pływalnię „Wodny Świat”, w której oprócz basenów i atrakcji wodnych mieści się również strefa odnowy biologicznej. Obiekt ten powstał nie tylko z myślą o kuracjuszach i mieszkańcach, ale również z myślą o turystach tu przybywających (Kłos 2010 - niepublikowane).

Podejmowane inwestycje świadczą o wzroście zainteresowania przyjazdami kuracjuszy do Horyńca, co potwierdzają również dane liczbowe zamieszczone w tabeli 2. W latach 1995-2008 nastąpił wzrost liczby kuracjuszy o 4812 osób (z 4859 w 1995 r. do 9671 w 2008 r.), czyli o 99\%. Wzrasta także liczba wykorzystanych łóżek sanatoryjnych i liczba osobodni leczenia. Warto podkreślić, że w 1996 r. liczba kuracjuszy lecznictwa zamkniętego przekroczyła liczbę stałych mieszkańców gminy Horyniec-Zdrój i dziś jest blisko dwukrotnie większa.

Tab. 2. Zmiany liczby turystów korzystających z noclegów w gminie Horyniec-Zdrój w latach 1995-2008

\begin{tabular}{|c|c|c|}
\hline Rok & $\begin{array}{c}\text { Turyści korzystający } \\
\text { z noclegów }\end{array}$ & $\begin{array}{c}\text { Dynamika } \\
\mathbf{1 9 9 5}=\mathbf{1 0 0 \%}\end{array}$ \\
\hline 1995 & 857 & 100,00 \\
\hline 1996 & 1469 & 171,41 \\
\hline 1997 & 1679 & 195,92 \\
\hline 1998 & 1988 & 231,97 \\
\hline 1999 & 2058 & 240,14 \\
\hline 2000 & 2100 & 245,04 \\
\hline 2001 & 2149 & 250,76 \\
\hline 2002 & 3126 & 248,07 \\
\hline 2003 & 5449 & 635,82 \\
\hline 2004 & 6459 & 753,68 \\
\hline 2005 & 6563 & 765,81 \\
\hline 2006 & 6734 & 785,76 \\
\hline 2007 & 6812 & 794,87 \\
\hline 2008 & 6868 & 801,4 \\
\hline
\end{tabular}

Źródło: opracowanie własne na podstawie danych GUS (www.stat.gov.pl).

Można stwierdzić, iż pomimo swojego peryferyjnego położenia Horyniec-Zdrój cieszy się dużym powodzeniem wśród kuracjuszy. Z jednej strony jest to zapewne konsekwencją tego, że nasze społeczeństwo się starzeje i coraz więcej osób potrzebuje fachowej opieki medycznej i rehabilitacji, którą zapewniają sanatoria. Ponadto wzrasta też poziom świadomości społeczeństwa i coraz częściej ludzie decydują się na pobyt w sanatorium w celach profilaktycznych. Rozwój funkcji uzdrowiskowej jest niewątpliwie zjawiskiem korzystnym, gdyż pociąga za sobą rozwój innych dziedzin działalności gospodarczej i wymusza niejako na władzach dbałość o ład przestrzenny gminy oraz o rozwój infrastrukturalny, co w przypadku uzdrowisk jest niezwykle istotne. 
Wraz z rozwojem funkcji uzdrowiskowej rozwija się także funkcja turystyczna gminy. Rozwój funkcji turystycznej, a co za tym idzie - wielkość ruchu turystycznego - ma odzwierciedlenie w liczbie osób korzystających z noclegów. Jak pokazują dane zawarte w tabeli 2, w badanym okresie czasu liczba turystów korzystających z noclegów na terenie gminy Horyniec-Zdrój wzrosła o 5955 osób (z 857 turystów w 1995 r. do 6868 turystów w 2008 r.), czyli o 701,4\%. Dynamicznej rozbudowie ulega także baza noclegowa gminy.

Połączenie przedsiębiorczości mieszkańców z rozwojem funkcji uzdrowiskowej i turystycznej w gminie oraz możliwościami, które to za sobą niesie, wpływa na aktywizację regionu, przejawiającą się głównie we wzroście liczby podmiotów gospodarczych świadczących usługi dla kuracjuszy i turystów, co zwiększa rynek pracy, powoduje wzrost dochodów ludności i samorządu oraz przyczynia się do ograniczenia bezrobocia. Potwierdzają to także dane statystyczne zamieszczone tabeli 3.

Tab. 3. Zmiany w liczbie podmiotów gospodarczych prosperujących w gminie Horyniec-Zdrój w latach 1995-2008

\begin{tabular}{|c|c|c|}
\hline Rok & $\begin{array}{c}\text { Liczba podmiotów } \\
\text { gospodarczych }\end{array}$ & $\begin{array}{c}\text { Dynamika } \\
\mathbf{1 9 9 5}=\mathbf{1 0 0 \%}\end{array}$ \\
\hline 1995 & 96 & 100,00 \\
\hline 1996 & 123 & 128,13 \\
\hline 1997 & 133 & 138,54 \\
\hline 1998 & 148 & 154,17 \\
\hline 1999 & 164 & 170,83 \\
\hline 2000 & 166 & 172,92 \\
\hline 2001 & 179 & 186,46 \\
\hline 2002 & 182 & 189,58 \\
\hline 2003 & 187 & 194,79 \\
\hline 2004 & 193 & 201,04 \\
\hline 2005 & 197 & 205,21 \\
\hline 2006 & 202 & 210,42 \\
\hline 2007 & 202 & 210,42 \\
\hline 2008 & 213 & 221,88 \\
\hline
\end{tabular}

Źródło: opracowanie własne na podstawie danych GUS (www.stat.gov.pl).

W gminie Horyniec-Zdrój w badanym okresie czasu liczba podmiotów gospodarczych zwiększyła się o 117 (z 96 w 1995 r. do 213 w 2008 r.), czyli nastąpił wzrost o 121,9\% w porównaniu z rokiem bazowym (1995). Na rycinie 2 wyraźnie widać, że w 2008 r. w strukturze zdecydowanie dominuje sektor usługowy (77,9\%), mniej stanowi sektor przemysłowy $(17,8 \%)$, najmniej - sektor rolniczy $(4,2 \%)$. 
Ryc. 2. Struktura podmiotów gospodarczych prosperujących w gminie Horyniec-Zdrój w 2008 r.

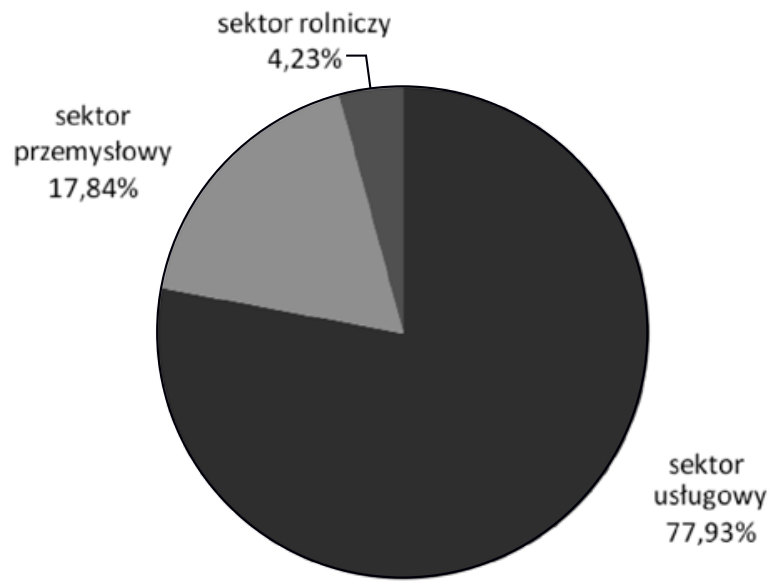

Źródło: opracowanie własne na podstawie danych GUS (www.stat.gov.pl).

Sytuacja ta potwierdza bardzo duże znaczenie usług w gospodarce gminy, co ma związek z rozwijającymi się na jej terenie funkcjami: uzdrowiskową i turystyczną, które pociągają za sobą rozwój regionu w sferze usług i wymuszają na mieszkańcach dostosowywanie profilu działalności do wymagań przybywających tu kuracjuszy i turystów.

Położenie Horyńca-Zdroju w takim rejonie, jakim jest obszar wschodniej Polski, gdzie rolnictwo charakteryzuje się niskim poziomem kultury rolnej, małą produktywnością, niskim poziomem towarowości i dużym rozdrobnieniem gospodarstw (Gorzelak 2000) tym bardziej przemawia za rozwojem takich form, jak działalność uzdrowiskowa czy turystyczna. Powstają nowe gospodarstwa agroturystyczne, pensjonaty, kawiarnie, a wzrost liczy podmiotów gospodarczych przekłada się na zmiany w poziomie bezrobocia, co potwierdzają dane zamieszczone w tabeli 4.

Stopa bezrobocia na badanym obszarze wykazuje tendencję malejącą. W latach 2002-2008 stopa bezrobocia zmalała o $7 \%$ (z 18,8\% w roku 2003 do $11,8 \% \mathrm{w}$ roku 2008). Jest to niewątpliwie sytuacja korzystna, świadcząca o rozwoju badanego regionu.

Tab. 4. Zmiany poziomu współczynnika bezrobocia w gminie Horyniec-Zdrój w latach 2002-2008

\begin{tabular}{|c|c|}
\hline Rok & Wspólczynnik bezrobocia (\%) \\
\hline 2002 & 18,8 \\
\hline 2003 & 18,6 \\
\hline 2004 & 18,1 \\
\hline 2005 & 16,0 \\
\hline 2006 & 13,4 \\
\hline 2007 & 12,4 \\
\hline 2008 & 11,8 \\
\hline
\end{tabular}

Źródło: opracowanie własne na podstawie danych GUS (www.stat.gov.pl). 
Przedsiębiorczość i aktywność mieszkańców jest zauważalna również w dbałości o otoczenie oraz kreowaniu pozytywnego wizerunku gminy. Z inicjatywy osób zainteresowanych społeczną działalnością na rzecz gminy Horyniec-Zdrój powstało Stowarzyszenie Przyjaciół Ziemi Horynieckiej. Obecnie liczy ono już 40 członków. Jest ono pomysłodawcą „Gazety Horynieckiej”, w której umieszczane są aktualności na temat gminy. Ponadto Stowarzyszenie realizuje projekt „Kresowe dziedzictwo - kamieniarstwo bruśnieńskie” dofinansowany z Programu Wsparcia Obszarów Wiejskich, z funduszy pozyskanych przez Urząd Gminy w Horyńcu-Zdroju. Projektem objęci są m.in. uczniowie wszystkich szkół Gminy Horyniec-Zdrój, a działania prowadzone w jego ramach to m.in. wycieczki i plenery fotograficzne dla młodzieży, gromadzenie materiałów dokumentujących zabytki kamieniarstwa bruśnieńskiego, tworzenie albumów i wystaw.

„Roztocze - Witalność z natury” to hasło projektu Lokalnej Organizacji Turystycznej Roztocze, projektu, który będzie realizowany na obszarze Roztocza. W jego ramach planowane jest postawienie kilkunastu turystycznych tablic informacyjnych z mapami regionu, a ponadto stworzenie kilku filmów dokumentalnych o Roztoczu (każdy odcinek będzie opowiadał o konkretnej gminie).

Aktywnie udziela się również Grupa Eksploratorów Roztocza Południowego (GERP), która od ponad roku realizuje projekt mający na celu przywrócenie dawnej świetności starym, zniszczonym krzyżom przydrożnym wykonanym z kamienia bruśnieńskiego. W okresie od kwietnia 2009 r. do lipca 2010 r. GERP udało się ocalić od zniszczenia siedem obiektów w najbliższych okolicach Horyńca-Zdroju.

Przytoczone tu przykłady to jedynie część działań i postaw przedsiębiorczych władz oraz mieszkańców gminy Horyniec-Zdrój, które są podejmowane w celu jej aktywizacji oraz podniesienia jej konkurencyjności. Pokazują one, w jaki sposób można wykorzystać specyfikę i potencjał endogeniczny obszaru, pomimo wielu trudności, które władze i mieszkańcy napotykają na swej drodze. W dobie globalnej konkurencji istotne jest bowiem dbanie o konkurencyjność i znalezienie sposobu na skuteczne przyciągnięcie kuracjuszy, turystów i potencjalnych inwestorów. Z globalizacji można jednak czerpać także korzyści, jak chociażby pozyskiwanie funduszy europejskich na realizację nowych inwestycji i projektów - tak jak ma to miejsce w gminie Horyniec-Zdrój.

W świetle przeprowadzonych badań można stwierdzić, że występuje związek pomiędzy postawami przedsiębiorczymi władz i mieszkańców a aktywizacją społeczno-gospodarczą regionu. Rozwój przedsiębiorczości ma bowiem fundamentalne znaczenie dla sukcesu całego obszaru. Realizacja nowych przedsięwzięć prowadzi do wzrostu produktywności i konkurencyjności na rynku, co zmusza również inne firmy do realizacji inicjatyw poprawiających ich efektywność lub reorientacji ich działalności. Rozwój przedsiębiorczości ma zatem bardzo istotne znaczenie $\mathrm{w}$ zwiększaniu poziomu zatrudnienia i w przyspieszaniu procesów wzrostu społeczno-gospodarczego.

\section{Literatura}

1. Fedan R., 2005, Rola przedsiębiorczości w aktywizacji ośrodków ponadlokalnych (na przykładzie Jarosławia) [w:] Przedsiębiorczość a wspótczesne wyzwania cywilizacyjne, Z. Zioło, T. Rachwał (red.), „Przedsiębiorczość - Edukacja”, nr 1, Wydawnictwo MiWa, Zakład Przedsiębiorczości i Gospodarki Przestrzennej i Instytutu Geografii Akademii Pedagogicznej w Krakowie, Kraków.

2. Golba J., 2002, Aktywizacja społeczno-gospodarcza gmin uzdrowiskowych jako podstawa ich rozwoju [w:] XI Kongres Uzdrowisk Polskich - Materiały Konferencyjne, Stowarzyszenie Gmin Uzdrowiskowych RP, Krynica-Zdrój.

3. Gorzelak G., 2000, Polska wschodnia - perspektywy rozwoju [w:] Narodowa strategia rozwoju regionalnego, J. Szlachta (red.), Biuletyn KPZK PAN, z. 191, Warszawa. 
4. Kaczmarska E., 2002, Uzdrowisko i jego przestrzeń społeczna. Wybrane zagadnienia przestrzenne polskich uzdrowisk karpackich $w$ aspekcie integracji europejskiej, „Zeszyty Naukowe Politechniki Krakowskiej. Seria Architektura", nr 47, Wydawnictwo Politechniki Krakowskiej, Kraków.

5. Kajoch A. (red.), 1990, Atlas uzdrowisk polskich, Państwowe Przedsiębiorstwo Wydawnictw Kartograficznych im. Eugeniusza Romera, Warszawa-Wrocław.

6. Kłos A., 2010, Analiza rozwoju funkcji uzdrowiskowej gminy Horyniec-Zdrój w latach 1995-2008 (niepublikowane).

7. Kudełko J., 2005, Rozwój regionalny a konkurencyjność regionów [w:] Uwarunkowania rozwoju regionu i konkurencyjność regionów, Instytut Gospodarki WSIiZ, Rzeszów.

8. Lokalna strategia rozwoju Grupy Działania ,, Serce Roztocza” na lata 2009-2015.

9. Plan odnowy miejscowości na lata 2007-2013.

10. Plan rozwoju lokalnego Gminy Horyniec-Zdrój na lata 2005-2013.

11. Program ochrony środowiska dla Gminy Horyniec-Zdrój 2005.

12. Majewska J., 2006, Wyzwalanie ducha przedsiębiorczości w środowisku społecznym gminy dla rozwoju lokalnego [w:] Rola przedsiębiorczości w podnoszeniu konkurencyjności społeczeństwa i gospodarki, Z. Zioło, T. Rachwał, „Przedsiębiorczość - Edukacja”, nr 2, Nowa Era, Zakład Przedsiębiorczości i Gospodarki Przestrzennej i Instytutu Geografii Akademii Pedagogicznej w Krakowie, Warszawa-Kraków. 13. Strategia rozwoju Gminy Horyniec-Zdrój na lata 2005-2013.

14. Ustawa z dnia 28 lipca 2005 r. o lecznictwie uzdrowiskowym, uzdrowiskach i obszarach ochrony uzdrowiskowej oraz o gminach uzdrowiskowych (Dz.U. z dnia 1 września 2005 r.)

15. www.mz.gov.pl

16. www.stat.gov.pl

17. www.ughoryniec.iap.pl

18. Zioło Z., 2007, Rola przedsiębiorczości w aktywizacji gospodarczej-zarys modelu [w:] Rola przedsiębiorczości w aktywizacji gospodarczej, Z. Zioło, T. Rachwał (red.), „Przedsiębiorczość - Edukacja”, nr 3, Nowa Era, Zakład Przedsiębiorczości i Gospodarki Przestrzennej i Instytutu Geografii Akademii Pedagogicznej w Krakowie, Warszawa-Kraków.

\section{Role of Entrepreneurship and the Government and Local Residents Horyniec-Zdrój in the Activation of the Region's Economy}

Horyniec-Zdrój is one of 44 statutory spa-resorts in Poland. This means that the development of the community is associated with many limitations, but it also entails many benefits. The spa-resort has an impact on the region's development through its influence on many aspects of different fields of life - it encourages the development of other forms of business activities, which if used appropriately can be a factor in local development.

The article examines the actions and initiatives of the authorities on how to use the resort features for the region's development, how to use EU funds, how to invest in the commune, and how to develop entrepreneurial attitudes.

In order to assess the activity of the population, the author analyzed changes in the employment in three sectors of the economy, the changes in the level of unemployment and the number of business entities in the community in the years 1995-2008.

The studies have contributed to explore the issues of the shaping of entrepreneurship in the Horyniec-Zdrój commune. The author has confirmed the positive effect of the actions of the authorities and residents on the economic activation of the region. 